\title{
New Mission for New Time in Korean Higher Education
}

\author{
Moon Sook Jeong ${ }^{\mathrm{a}, *}$ \\ ${ }^{a}$ Korea University of Technology and Education, South Korea \\ *Corresponding author: Email: barbramoon1@gmail.com \\ Address: Korean University of Technology and Education, Cheonan, Chungnam Province, South Korea
}

\section{Introduction}

In the 1990s, South Korea (Korea hereafter) was confronted with a new social environment, characterized as globalization and knowledge-based economy. In order to respond to the new environment, there have been considerable reform efforts in Korea higher education over the past two decades. Universities in Korea accordingly transformed their educational structures and contents while becoming familiar with policy buzz words such as change, reform, restructuring, and innovation. Scholarly works identified the feature of Korean higher education reform during that time as neo-liberal and this policy reform thrust was analyzed with both international and domestic pressures (Kim 2010; Jeong 2012; Yim 2012 as cited in Jeong, 2014a). As a result, neo-liberal market principles like competition, marketization, and decentralization (autonomy and accountability) were settled down in policy practice (Jeong 2014a), while creating unique locality in policy appropriations (Kang 2004; Jeong 2014b). Neo-liberalism was highlighted as the fundamental mechanism of extensive reform in Korean higher education in national funding projects which were executed as strong governance in the country (Kim 2008, Jeong 2014b). It should not be overlooked that the other powerful mechanism of reform, ideological process, significantly affected educational change in Korea (Jeong 2015).

Subsequent to an educational reform fever for globalization and knowledge-based economy, Korean higher education entered into another stage of megaturbulence. Indeed, there was a strong tension about the sustainability of university education connected to a new social environment which is distinguished from the one in the twentieth century. Recognizing this atmosphere, I, insider of Korean higher education and a critical researcher in the field of Educational Policy Studies, feel the responsibility to answer the question, "what is a dominant policy discourse in current Korean higher education?' based on the questions of "what is going on now in Korean higher education?" To answer the above question, I will figure out emerging policy issues in Korean higher education and look into how a dominant policy discourse is created and operated as a policy imperative in Korea. By doing so, I wish this short study reveals a policy response of Korean higher education to new social change, while providing the source of Korean case for the development of the comparative and international education.

\section{Higher Education in Korea}

As of April 2018, 3,378,393 students are enrolled for 430 higher education institutions in Korea (Korean Educational Statistics Service). Among them, four-year universities are 68 percent (293 institutions) and include special purpose universities (e. g., university of education, industrial universities, polytechnic colleges) with 64.5 percent of students $(2,719,161)$ of all. I constrain the scope of Korean higher education to fouryear universities in this paper. In speaking of Korean higher education, there are some characteristics such as foundation of western ideology and Confucian tradition, a high rate of enrollment, heavy reliance on private sources (student tuition), a historical tie with country's economic development, institutional hierarchical order among institutions and central government's control over institutional management for decades (Jeong 2015). Big challenges in current Korean higher 
education are rapid demographic decline and a high unemployment rate of university graduates. Recently, Korean universities have had a difficulty in recruiting students for their admission quotas because of country's low fertility (The Korean Times 2015; Yonezawa and Kim 2008). Another issue is youth unemployment. Contrast to a high rate of university enrollment (71 percent in 2015, Ministry of education), university graduates in Korea hardly are able to find jobs and contribute to the country's unemployment rate (3.7 percent in Aug. 2018) which was different from previous years (Lee 2018) when Korean higher education largely contributed to a national economic growth by providing labor force in its society and enabled individuals' social mobility.

\section{New Mission for New Time}

\section{The Fourth Industrial Revolution}

Korean higher education currently identifies a new social environment that follows globalization and knowledge-based economy. This environment is newly conceptualized in an economic community. Being equivalently regarded as Industry 4.0 in Germany, Schuwab, who is the executive chairman of the World Economic Forum officially coined the term, "the Fourth Industrial Revolution" to describe the characteristics of current society. According to Klaus Schuwab (2016), the twenty-first century is "revolutionary" in terms of its unprecedented impact, scale and speed that bring significant changes of economic, and social systems with disruptive technologies. This Revolution is the "Fourth" in human history and is the most powerful industrial transformation compared to the other three. The first revolution was around the early nineteenth century which was triggered by the steam engine. The second revolution was around the early twentieth century which was triggered by mass production. The third revolution in the late twentieth century was triggered by digital advancement (computing to internet). In the current, the Fourth revolution, a key feature is a transcendent connectivity among people and organizations by technology advance and the potential of management excellence in all aspects of society. This digitization society influences education in a way that a new paradigm of learning is required to individuals, so that educational institutions are endeavored to provide those pedagogical process for their students and society further. Academia seriously pays attention to the Fourth Industrial Revolution and expresses the opinion that higher education should respond to this revolutionary time and consider innovative changes to educate the next generation (Baik 2017; Gleason 2018; Hirota 2017; Jho 2017; Xing and Marwala 2017). In Korean context, therefore, it is a societal condition that universities are faced with regarding to curriculum management and graduate employment that leads them to survive in the competition of financial source (both student recruitment and national subsidies).

\section{Competency-Based Education}

A new mission has been given to Korean higher education for the new time. In recent years, specific themes have arisen in educational policies in Korea for the necessity of individual capacity building. Those are creativity, convergence education (Yunghap or Yungbokhap Kyoyuk in Korean, contextually similar to integrated or interdisciplinary studies in other countries' educational practice), critical thinking skill, communication skill, community leadership and so on. Educational policy makers in Korea diagnose those skills or abilities as individuals' capacities to be equipped with in the future society and they are accommodated as must-do elements for teaching and learning in educational practice. These emerging themes are defined as 'competency' in policy discourse of Korean higher education and appear at each university level policies. In DeSeCo (Definition and Selection of Competencies) project initiated by the Organization of Economic Cooperation and Development (OECD), "competence, -ies" was broadly conceptualized as "the ability to meet demands of a high degree of complexity, and implies complex action systems" differed from the concepts of knowledge (understood body of information) and skills (ability to use knowledge) in the premise of learning process within the set of planned system contrast to innate characteristics (Rychen and Salganik 2010, 8-9). 
In Korea, the concept of competency was generally understood as a skill to achieve given tasks successful in work place (So 2006), but later extended to "a comprehensive skill to lead one's life successful through the ability to do something rather than the ability to accumulate knowledge" (So 2009). Regarding to the learning system, competency-based education in higher education focuses on the curriculum development to improve personal achievement (Park, 2008). In this regard, university education in Korea is desired to be guided from "what one knows" to "what one can do" for competency-based education. As a breakthrough of the Fourth Industrial Revolution, competency-based education has become a hot issue for both national and university policy makers in Korea and imprinted in educational policy documents as an (urgent) imperative to Korean higher education. That is, a policy paradigm of higher education in Korea is being shifted with the rationale of the Fourth Industrial Revolution.

\section{Policy Discourse}

\section{Persuasion}

A policy goal setting for this new social environment, needless to say, comes with an ideological process and national funding projects. Similar to the era of globalization and knowledge-based economy, educational policy makers in Korea took up the discourse of the Fourth Industrial Revolution from a global policy network (i.e., World Economic Forum) and a political arena of the country (i.e., president election in 2017) seriously justified this new phenomenon as a national alert. For example, a current ruling party presented a pledge for country's educational system that prepares for the era of the Fourth Industrial Revolution, and the other president candidate (Ahn) made an electoral pledge as "Let's prepare for the ground of the Fourth Industrial Revolution" and education was its first strategy (the Central Election Management Committee)". Since then, the clear feature of this technology-advanced social environment is engraved in educational stakeholders' minds.

Not much different from the Fourth Industrial Revolution, the idea of competency became critical to Korean education developed by the ideological process between global and local policy network. The discourse of competency was initiated by a global policy network, the OECD that performed the DeSeCo project and reported future individuals' core competencies in 2003. Core competencies of this project are using tools interactively, interacting in heterogeneous groups, and acting autonomously. Taking the OECD idea seriously, the Korean government announced the visions and strategies of future education through the Presidential Committee on Educational Innovation in 2007 and emphasized a paradigm shift in education from knowledge transfer to competency enhancement. This national level discussion was moved to K-12 level educational curriculum in 2009 and finally reflected to the Revision of National Curriculum with six core competencies in 2015. Those six are self-management competency, knowledge/information processing competency, creative thinking competency, aestheticemotional competency, communication competency, and civic competency. At a higher education level, competency-based education was empowered with the rationale of educational quality improvement that leads to the solution of youth unemployment and the uncertainty in the Fourth Industrial Revolution.

\section{Governance}

In the arising policy discourse, competency is legitimized by university evaluation methods which are powerful tools to drive institutional restructuring with huge financial support. National funding programs in Korean higher education have largely supported for graduate research, university specialization (currently eight programs belong to this category) and industryuniversity cooperation. National subsidies are distributed to universities over the country and the assessment criteria of these funding implicitly and explicitly evaluate competency-based curriculum as an important index of university restructuring. Among them, there is a specific national funding project that has promoted students' competency development to universities directly, called Advancement of College Education (ACE). This project was implemented during 2010-2016 for 32 universities and continued as a follow-up project, ACE+. This project targets undergraduate programs and includes the improvement 
of competency in teaching and learning for its evaluation criteria with institutional autonomy.

Another example is the University Basic Competency Evaluation (daehak kibon yeokryang jindan) - one of influential university evaluations associated with a national budget distribution to Korea higher education. The evaluation system was called "University Restructuring Evaluation" in 2015 and again performed by the central government (Ministry of Education) in 2018 for universities and colleges in South Korea (special purposed universities such as normal university, religion or arts school and some of merging planned universities excluded) to enhance university competitiveness in Korea by a rigorous selection process with various criteria. The lowest ranked universities have financial restrictions from the government and finally have damage to student recruitment. The Evaluation clearly indicates that this evaluation is initiated to prepare for the advent of the Fourth Industrial Revolution, demographic change and finally pursues university competitiveness of Korean higher education through educational quality improvement (Centre for University Basic Competency Evaluation). Consequently, most universities in Korea create core competencies for their own educational vision and goals while considering university curriculum organization for students' competency enhancement. In the time of student shortage, Korean universities choose to rely on national subsidies for their financial sources.

It is noteworthy that a nation-wide competency assessment tool (Korea Collegiate Essential Skills Assessment, K-CESA) has been provided since 2010 for university students' self-assessment of essential workplace skills, so that each university utilizes the assessment result for their curriculum development and career guide. K-CESA assesses six job essential skills: communication, comprehensive reasons, resource, information, technology handling, global readiness, self-management, and interpersonal relationship. Moreover, Korea joined the OECD's international comparison system of competency evaluation that allows member countries' peer-review of general skill strand. The system, called the Assessment of Higher
Education Learning Outcomes (AHELO) measures problem solving skills, critical thinking skills, analytical reasoning, written communication, and so on. In addition to national subsidies, these assessment instruments systematically help competency-based education to be rooted in Korean higher education.

\section{Rational and Reality}

There is ongoing controversy over the new mission. One may suggest that competency-based education is a new compass for future talent nurturing in higher education and the key to improve both university and individuals' competitiveness domestically and internationally. For instance, competencies like creativity and interdisciplinary/integrative education are cultivated when university curriculum is re-organized by innovating traditional classification of university education (e.g., creation of linkage by two or more academic disciplines or projects) and its evaluation (e.g., curve grading to absolute grading or $\mathrm{ABC}$ grading to competency-based grading). Introducing the case of competency-based education at some US universities, Rhew (2018) suggests that competency-based education may help Korean universities by bringing an opportunity of educational innovation in the era of the Fourth Industrial Revolution.

On the contrary, there is a concern about a theoretical background on competency-based education due to its vocational ground (or job performance) rather than educational needs (Kim \& Kim 2017) and has a basis on neoliberal ideology (Hu 2016; Son and Jo 2016). It is important that this experimental policy should not be overflow in speed in educational practice. In their empirical study, Kim and Lee (2012) emphasized a longterm monitoring plan on students' learning outcome and well-structured curriculum for competency development. Competency-based university education has not fully accommodated to a university level yet and nobody is sure whether it is even applicable to current academic disciplines or not, creating space for 'self-learning possibility'. Rather, competency-education may mislead students to be subjugated to specific goal intended curriculum (Kim 2018). 


\section{Conclusion}

Borrowing this space, I introduced an emerging policy discourse of Korean higher education in a newly identified social environment and briefly discussed how this policy discourse is reflected in policy practice as an important indicator for educational paradigm change in Korea. The Fourth Industrial Revolution replaces globalization and knowledge-based economy and competency-based education and takes the place of neoliberalism in Korean higher education. In other words, the Fourth Industrial Revolution is being accepted as "taken-for-granted" and "unavoidable" social environment to educational stakeholders in Korea accompanied by the ideological consensus between global and local policy network. Demographic decline is undeniable fact that promotes university quality improvement so that university can fill their student quotas and finally survive. Beyond a controversy over theoretical backgrounds and practical viability, the discourse of competency has been "soft-landed" in an identified social environment of Korean higher education. That is, Korean higher education embraces the challenges (competency-based education) in corresponding to the new social environment, the Fourth Industrial Revolution and demographic decrease.

Here, some other thoughts remain to be considered. Educational policy should keep the balance between a technology-advanced environment (even it is overarching) and other social impacts that influence Korean society and its education (e. g., cultural dynamics). For new mission in Korean higher education - competency-based education, what should be considered more for policy implementation at this stage? To what extent this policy discourse can be carried out in policy practice. For any of educational policy discourse and its underpinned rationale, educational concern should go first. In other words, the consideration of "educational" return to both individuals and society must be the basis of policy discourse. Competencies like creativity, critical thinking, comprehensive understanding on multidisciplinary sources, communication skills should help individuals genuinely grow (beyond a survival in job competition) as a human being in a highly technology advanced society and further assist the society to be prospered. For policy implementation, policy practice should keep its "locality". That is to say, each university in Korea should keep its own educational values when interact with the upper-level policy discourse even in the condition that universities have no other options to survive in a demographic decline. It is because the future of university education in Korea depends on not macro-level policy makers, but policy practice.

\section{References}

The Centre for University Basic Competency. n.d. Accessed November 30, 2018. http://uce.kedi.re.kr/index.do

Gleason, Nancy, ed. 2018. Higher Education in the Era of the Fourth Industrial Revolution. Singapore: Palgrave Macmillan.

The Central Election Management Committee. n.d. Accessed November 30, 2018. http://policy.nec.go.kr/

Hirota, D. 2017. "Educational Challenges to Respond to the Fourth Industrial Revolution: Japanese Case." Keynote speech presented at 2017 Conference of Korean Educational Research Association, Chungnam University (Daejeon).

Hur, Young Ju. 2016. "A Study in the Direction and Strategies for the Reorganization of the Liberal Arts Curriculum Based on the NCS Professional Basic Ability." Korean Journal of General Education 3 (10): 425-462.

Jho, Hunkoog. 2017. "The Changes of Higher Education and the Tasks of General Education according to the Fourth Industrial Revolution." Korean Journal of General Education 11 (2): 53-89.

Kang, Tae-jung. 2004. "A Critique of the NeoLiberalistic Conception of Higher Education Reform in Korea." The Research Institute of Korean Educational Issue 19: 41-57.

Kim, Min-jung. 2018. "Critical Reflection and Consideration of Alternative possibility on Competency-based University Education." Paper 
presented at 2018 Spring Nation-wide Academic Conference: Curriculum Organization and Management. Seoul, Korea: Yonsei University, the Korea Association of General Education, Korea national institute for General Education, and Korean Association for Logic.

Kim, Hyeyoung and Sook-Jeong Lee. 2012. Diagnosis and Direction of the Competence-Based Educational Model: Based on the Courses and Effects. Korean Journal of General Education 6 (4): 11-40.

Kim, Dae-jung and So Young Kim. 2017. Understanding and Issues on Core Competency and Competencybased Curriculum in Higher Education 2 (1): 23-45. The Korea Association for Core Competency Education. Sejong: Republic of Korea.

Kim, Terri. 2008. Higher Education Reforms in South Korea: Public-private Problems in Internationalizing and Incorporating Universities. Policy Futures in Education 6 (5): 558-568.

Korean Educational Statistics Services. n.d. Accessed February 2, 2018. https://kess.kedi.re.kr/index, $\mathrm{http} / / /$ www.moe.go.kr/sub/info.do?m=040603\&s=moe Jeong, Jin-hee. 2012. "Neoliberal Education Policies and the Changes of Universities in South Korea." Doctoral dissertation. Jinjoo, Republic of Korea: Kyungsang University.

Jeong, Moon Sook. 2014a. "A Counter-hegemonic State to Neoliberalism: The Case of Recent Korean Higher Education Reforms." Comparative \& International Higher Education 6: 64-68.

Jeong, Moon Sook. 2014b. "The Role of the State in Neoliberal Reforms of Korean Higher Education. In A Comparative Analysis of Higher Education Systems, edited by Moon Sook Jeong, 111-122. Rotterdam: Sense Publishers.

Jeong, Moon Sook. 2015. "Localization of Global Discourse and the Breakdown of the Washington Consensus (WC): A Case Study of Korean Higher Education Reform (1993-2012)”. Doctoral dissertation, University of Alberta.

Lee, Claire. 2018. "Youth unemployment reaches 19year high in South Korea." Korea Herald, August $22,2018$. http://www.koreaherald.com/view.php?ud=201808 22000767

Ministry of Education. n.d. Accessed November 30, 2018. http://english.moe.go.kr/sub/info.do?m=020105\&s=en glish

The Organization of Economic Cooperation and Development (OECD). 2018. "Country Statistical profile: Korea 2018". https://www.oecdilibrary.org/docserver/csp-kor-table-2018-4en.pdf?expires $=1543647685 \& \mathrm{id}=\mathrm{id} \&$ accname $=$ guest $\& \mathrm{c}$ hecksum=4C2009DC5D93DB290621656EEC0BC6D8

Paek, Seung-soo. 2017. Search for Direction of Liberal Arts Education in the era of the Fourth Industrial Revolution. Korean Journal of General Education 11 (2): 13-51.

Park, Min-jung. 2008. A New Approach to Curriculum Development in Higher Education. Curriculum Study 26 (4): 173-197.

Penprase, Brayan Edward. 2018. "The Fourth Industrial Revolution and Higher Education." In Higher Education in the Era of the Fourth Industrial Revolution, edited by Nancy Gleason, 207-29. Singapore: Palgrave Macmillan.

Rhew, Tae-ho. (2018). Academic Report without Score. Seoul: Kyunghee University Publishing.

Rychen, Dominique Simone, and Laura Hersh Salganik 2010. "A Contribution of the OED Program Definition and Selection of Competencies: Theoretical and Conceptual Foundations," INES GENERAL ASSEMBLY 2000. Accessed November, 20, 2018.

http://www.orientamentoirreer.it/sites/default/files/ materiali/2000\%20deseco\%20contributo.pdf

Schwab, Klaus. 2016. The Fourth Industrial Revolution. Geneva: World Economic Forum.

So, Kyung Hee. 2009. Curricular-historical Base and Its Liberal Nature of Competence-based Education. Curriculum Study 27 (1): 1-20.

Son, Minho, and Hyun-young Jo. (2016). The Postfunctionalist Curriculum Model and a Metaphor of Identity: A Design for a Competence-based Curriculum. Curriculum Study 32 (2): 141-160. 
Xing, Bo, and Tshilidzi Marwala 2017. Implications of the Fourth Industrial Age on Higher Education. The Thinker, 73(third quarter).

https://ssrn.com/abstract=3225331

Yoon, Min-sik. 2015. "University Enrollment Decreases for First Time." The Korea Times, August 27, 2015.

http://www.koreaherald.com/view.php?ud=201508 27001089
Yonezawa, Akiyoshi, and Terri Kim. 2008. "The Future of Higher Education in the Context of a Shrinking Student Population: Policy Challenges for Japan and Korea." in Higher Education to 2030 (Vol.1): Demography. Paris: OECD Publishing. doi: https://dx.doi.org/10.1787/9789264040663-8-en 